\title{
Comparative Study on Keeping Quality of Market Ghee Samples
}

\author{
Niranjan $^{1 *}$, C. Kempanna ${ }^{2}$, Akshaykumar $^{3}$, B.G. Shilpashree ${ }^{2}$, \\ G. Poojitha ${ }^{4}$ and Pralhad ${ }^{5}$ \\ ${ }^{1}$ Hatsun Agro Products, Chennai, India \\ ${ }^{2}$ Dairy Science College, Hebbal, Bengaluru, India \\ ${ }^{3}$ ICAR-Krishi Vigyan Kendra, Bidar, India \\ ${ }^{4}$ College of dairy technology, Shri Venkateshwara veterinary university, Tirupati, India \\ ${ }^{5}$ ICAR-Krishi Vigyan Kendra Raichur, UAS, Raichur, India \\ *Corresponding author
}

\section{A B S T R A C T}

\section{Keywords}

Keeping quality, Ghee, Peroxide value, Free fatty acid

\section{Article Info}

Accepted:

18 August 2020

Available Online:

10 September 2020
Unlike all other indigenous milk products, ghee has a remarkably long keeping quality. The keeping quality of ghee is adversely affected by increase in acidity and development of oxidized off-flavours. Therefore, the flavour stability of ghee is usually assessed by estimating free fatty acids and peroxide value. The study was conducted to know the storage stability of market ghee samples collected from organized and unorganized sector in Bengaluru stored at $60^{\circ} \mathrm{C}$ during the storage period of 25 days. Peroxide value (PV) and free fatty acids (FFA) of ghee samples were analyzed during the study. The study revealed that peroxide value and FFA values were higher in the unorganised sector ghee samples indicating lower storage stability compared to control and organised sector of market ghee samples at elevated storage temperature of $60^{\circ} \mathrm{C}$.

\section{Introduction}

Ghee is important part of human diet. It is the most important ingredient in food and it is rich source of dietary energy and contains high calorific value. The Ghee contains certain acids which are very important and essential for the human beings. They are vehicle for the fat soluble vitamins (Jariwala, 2014). Dietary lipids, naturally occurring in raw food materials or added during food processing, play an important role in food nutrition and flavour. Meanwhile, lipid oxidation is a major cause of food quality deterioration, and has been a challenge for manufacturers and food scientists alike (Meghwal, 2011). Ghee undergoes oxidative degradation during storage (Shende et al., 2014; Gandhi et al., 2013; Pawar et al., 2012) and the extent of degradation depends mainly on storage temperature (controlling factor formation attaining ghee state either in liquid or solid state), oxygen availability (in unpacked, packed, type of package etc.) and ghee condition (liquid or solid state). Oxidative deterioration degrades color, flavor, 
aroma and nutritive value of ghee affecting suitability for consumption and reducing shelf-life of the product (Choe and Min, 2006; Shende et al., 2014; Gandhi et al., 2013; Pawar et al., 2012). Lipid oxidation lowers the sensory perception, nutritional quality and safety of lipids. The oxidation makes the food unacceptable to the consumer and causes great economic losses to the food industry. Therefore the present study was carried out to investigate the storage stability of market ghee samples (organized and unorganized) stored at $60^{\circ} \mathrm{C}$ during the storage period of 25 days. Samples are periodically evaluated by analytical methods like peroxide value (PV) estimation and free fatty acid (FFA) content to detect oxidation changes.

\section{Materials and Methods}

\section{Chemicals and reagents}

All the chemicals used during the investigation were AR grade and procured from standard suppliers (HI MEDIA®).

\section{Preparation of ghee}

Pure ghee was prepared by using the cream obtained from student experiment dairy plant (SEDP), Dairy science college, Bengaluru. The cream was taken in a stainless steel vessel and continuously heated at $120^{\circ} \mathrm{C}$ to remove the moisture and at the final stage of clarification the temperature was maintained at $120^{\circ} \mathrm{C}$ till the residue turns coffee brown colour. The ghee was cooled and filtered using muslin cloth and stored in stainless steel container for further use.

\section{Ghee samples}

Samples of ghee from organized sector (samples A, B, C, D and E) and unorganized sector (samples F, G, H and I) were collected from local market of Bengaluru to compare the storage stability with pure ghee control sample prepared.

\section{Storage of ghee samples}

The ghee prepared at laboratory, Market (organized and unorganized) ghee samples stored triplicate at $60^{\circ} \mathrm{C}$ in $500 \mathrm{ml}$ glass bottles with air tight interchangeable stoppers for $0,5,10,15,20,25$ days. Samples of ghee (about 50g) were drawn after mixing on $0^{\text {th }}$, $5^{\text {th }}, 10^{\text {th }}, 15^{\text {th }}, 20^{\text {th }}$ and $25^{\text {th }}$ day to evaluate the auto-oxidative stability and hydrolytic rancidity during storage.

\section{Determination of moisture of ghee}

The moisture content of ghee samples was determined by the method as described in SP: 18 (Part XI) - 1981.

\section{Determination of peroxide value}

The peroxide value of ghee samples was determined in subdued artificial light by Lea's method as described in AOAC, 965.33.

\section{Determination of free fatty acid value in ghee}

FFA content of ghee sample was determined as per SP: 18 (Part XI) - 1981.

\section{Statistical analysis}

The data was analyzed using $\mathrm{R}$ software $\{\mathrm{R}$ Programme, R-Version 3.1.3(2015-3-09), Copyright (C) 2015\} both one way and two way Completely Randomed Design (CRD) which is the most appropriate for the study.

\section{Results and Discussion}

\section{Gross composition of ghee samples}

Samples of ghee procured from market (organized and unorganized) and pure control 
ghee sample were analyzed for fat, moisture and free fatty acid (FFA) content.

The fat content of the pure ghee control sample was found to contain 99.62 per cent and the fat content of organised sector ghee samples ranged from 99.38 to 99.69 while unorganised sector ghee samples procured from the market were ranged between the per cent fat of 99.30 (brand I) to 99.42 (brand G). Sample D recorded the highest fat of 99.69 per cent. The moisture content of the control and organised sector ghee samples were ranged from 0.31 to 0.59 per cent where as the values were ranged between 0.58 (brand G) to 0.70 (brand I) in unorganised sector ghee samples. The data reveals that the FFA content of the control ghee sample was found to be $0.6 \% \mathrm{OA}$, while the values of other organised sector ghee samples FFA content were ranged from 0.27 (brand E) to $0.72 \%$ OA (brand D) where as the unorganised sector ghee samples showed fluctuations in FFA ranging from 0.40 (brand $F$ ) to 0.93 (brand I) \% OA (Table 1).

Table.1 Gross composition of ghee samples

\begin{tabular}{|c|c|c|c|c|c|c|c|c|c|c|}
\hline \multirow{2}{*}{ Composition } & \multicolumn{9}{|c|}{ Ghee samples } \\
\cline { 2 - 10 } & Control & \multicolumn{4}{|c|}{ Organised sector } & \multicolumn{3}{c|}{ Unorganised sector } \\
\cline { 3 - 10 } & & $\mathbf{A}$ & $\mathbf{B}$ & $\mathbf{C}$ & $\mathbf{D}$ & $\mathbf{E}$ & $\mathbf{F}$ & $\mathbf{G}$ & $\mathbf{H}$ & $\mathbf{I}$ \\
\hline Fat(\%) & 99.62 & 99.43 & 99.51 & 99.58 & 99.69 & 99.38 & 99.4 & 99.42 & 99.4 & 99.3 \\
\hline Moisture(\%) & 0.38 & 0.57 & 0.49 & 0.42 & 0.31 & 0.62 & 0.6 & 0.58 & 0.6 & 0.7 \\
\hline $\begin{array}{c}\text { Free fatty acids } \\
\text { (\% Oleic acid) }\end{array}$ & 0.6 & 0.33 & 0.53 & 0.63 & 0.72 & 0.27 & 0.4 & 0.83 & 0.4 & 0.93 \\
\hline
\end{tabular}

Note:

All the results are average of three trials.

Similar superscripts indicate non - significance at the corresponding critical difference

Statistical analysis was made only with the control ghee sample.

Table.2a Effect of peroxide value on organised sector ghee samples stored at $60^{\circ} \mathrm{C}$

\begin{tabular}{|c|c|c|c|c|c|c|}
\hline \multirow{2}{*}{$\begin{array}{c}\text { Ghee } \\
\text { samples }\end{array}$} & \multicolumn{6}{|c|}{ Peroxide value (m.Mol O $/$ Kg) } \\
\cline { 2 - 7 } & \multicolumn{5}{|c|}{ Storage time (in Days) } \\
\cline { 2 - 7 } & $\mathbf{0}$ & $\mathbf{5}$ & $\mathbf{1 0}$ & $\mathbf{1 5}$ & $\mathbf{2 0}$ & $\mathbf{2 5}$ \\
\hline Control & 0 & $0.40^{\mathrm{a}}$ & $0.90^{\mathrm{a}}$ & $1.40^{\mathrm{a}}$ & $3.50^{\mathrm{a}}$ & $6.00^{\mathrm{a}}$ \\
\hline $\mathbf{A}$ & 0 & $0.30^{\mathrm{b}}$ & $0.70^{\mathrm{a}}$ & $1.20^{\mathrm{a}}$ & $3.40^{\mathrm{a}}$ & $5.80^{\mathrm{a}}$ \\
\hline $\mathbf{B}$ & 0 & $0.50^{\mathrm{a}}$ & $0.90^{\mathrm{a}}$ & $1.50^{\mathrm{a}}$ & $3.70^{\mathrm{a}}$ & $6.10^{\mathrm{a}}$ \\
\hline $\mathbf{C}$ & 0 & $0.40^{\mathrm{a}}$ & $0.90^{\mathrm{a}}$ & $1.40^{\mathrm{a}}$ & $3.60^{\mathrm{a}}$ & $6.00^{\mathrm{a}}$ \\
\hline $\mathbf{D}$ & 0 & $0.50^{\mathrm{a}}$ & $0.80^{\mathrm{a}}$ & $1.20^{\mathrm{a}}$ & $3.40^{\mathrm{a}}$ & $6.00^{\mathrm{a}}$ \\
\hline $\mathbf{E}$ & 0 & $0.30^{\mathrm{a}}$ & $0.70^{\mathrm{a}}$ & $1.30^{\mathrm{a}}$ & $3.40^{\mathrm{a}}$ & $6.20^{\mathrm{a}}$ \\
\hline $\mathbf{C D}(\mathbf{P}<\mathbf{0 . 0 5})$ & & $\mathbf{N S}$ & $\mathbf{N S}$ & $\mathbf{N S}$ & $\mathbf{N S}$ & $\mathbf{N S}$ \\
\hline
\end{tabular}

Note:

All the results are average of three trials.

Similar superscripts indicate non - significance at the corresponding critical difference

Statistical analysis was made only with the control ghee sample.

NS - non-significant 
Table.2b Effect of peroxide value on un-organised sector ghee samples stored at $60^{\circ} \mathrm{C}$

\begin{tabular}{|c|c|c|c|c|c|c|}
\hline \multirow[t]{3}{*}{ Ghee samples } & \multicolumn{6}{|c|}{ Peroxide value (m.Mol $\mathrm{O}_{2} / \mathrm{Kg}$ fat) } \\
\hline & \multicolumn{6}{|c|}{ Storage time in Days } \\
\hline & $\mathbf{0}$ & 5 & 10 & 15 & 20 & 25 \\
\hline Control & 0 & $0.40^{\mathrm{a}}$ & $0.90^{\mathrm{a}}$ & $1.40^{\mathrm{a}}$ & $3.50^{\mathrm{a}}$ & $6.00^{\mathrm{a}}$ \\
\hline $\mathbf{F}$ & 0 & $0.60^{\mathrm{a}}$ & $1.00^{\mathrm{a}}$ & $1.70^{\mathrm{a}}$ & $3.80^{\mathrm{b}}$ & $6.25^{\mathrm{a}}$ \\
\hline $\mathbf{G}$ & 0 & $0.60^{\mathrm{a}}$ & $1.10^{\mathrm{a}}$ & $1.40^{\mathrm{a}}$ & $3.40^{\mathrm{a}}$ & $7.50^{\mathrm{b}}$ \\
\hline $\mathbf{H}$ & 0 & $0.60^{\mathrm{a}}$ & $0.98^{\mathrm{a}}$ & $1.70^{\mathrm{a}}$ & $3.50^{\mathrm{a}}$ & $6.20^{\mathrm{a}}$ \\
\hline I & 0 & $0.50^{\mathrm{a}}$ & $0.96^{\mathrm{a}}$ & $1.60^{\mathrm{a}}$ & $3.70^{\mathrm{a}}$ & $7.60^{b}$ \\
\hline $\mathrm{CD}(\mathrm{P}<\mathbf{0 . 0 5})$ & \multicolumn{2}{|c|}{ NS } & NS & NS & 0.25 & 0.30 \\
\hline
\end{tabular}

Note:

All the results are average of three trials.

Similar superscripts indicate non - significance at the corresponding critical difference

Statistical analysis was made only with the control ghee sample.

NS - non-significant

Table.3a Effect of FFA on organised ghee samples stored at $60^{\circ} \mathrm{C}$

\begin{tabular}{|c|c|c|c|c|c|c|}
\hline \multirow{2}{*}{ Ghee samples } & \multicolumn{7}{|c|}{ FFA \% Oleic acid } \\
\cline { 2 - 6 } & \multicolumn{7}{|c|}{ Storage time (in Days) } \\
\cline { 2 - 7 } & $\mathbf{0}$ & $\mathbf{5}$ & $\mathbf{1 0}$ & $\mathbf{1 5}$ & $\mathbf{2 0}$ & $\mathbf{2 5}$ \\
\hline Control & $0.60^{\mathrm{a}}$ & $0.65^{\mathrm{a}}$ & $0.68^{\mathrm{a}}$ & $0.70^{\mathrm{a}}$ & $0.74^{\mathrm{a}}$ & $0.80^{\mathrm{a}}$ \\
\hline $\mathbf{A}$ & $0.33^{\mathrm{a}}$ & $0.56^{\mathrm{b}}$ & $0.60^{\mathrm{a}}$ & $0.63^{\mathrm{a}}$ & $0.67^{\mathrm{a}}$ & $0.72^{\mathrm{a}}$ \\
\hline $\mathbf{B}$ & $0.53^{\mathrm{a}}$ & $0.68^{\mathrm{a}}$ & $0.70^{\mathrm{a}}$ & $0.72^{\mathrm{a}}$ & $0.75^{\mathrm{a}}$ & $0.81^{\mathrm{a}}$ \\
\hline $\mathbf{C}$ & $0.72^{\mathrm{a}}$ & $0.76^{\mathrm{a}}$ & $0.88^{\mathrm{a}}$ & $0.91^{\mathrm{a}}$ & $0.94^{\mathrm{a}}$ & $0.96^{\mathrm{a}}$ \\
\hline $\mathbf{D}$ & $0.27^{\mathrm{b}}$ & $0.41^{\mathrm{b}}$ & $0.44^{\mathrm{b}}$ & $0.47^{\mathrm{b}}$ & $0.51^{\mathrm{b}}$ & $0.57^{\mathrm{b}}$ \\
\hline $\mathbf{E}$ & $0.30^{\mathrm{b}}$ & $0.42^{\mathrm{b}}$ & $0.46^{\mathrm{b}}$ & $0.50^{\mathrm{a}}$ & $0.53^{\mathrm{b}}$ & $0.60^{\mathrm{a}}$ \\
\hline $\mathbf{C D}(\mathbf{P}<\mathbf{0 . 0 5})$ & $\mathbf{0 . 2 9}$ & $\mathbf{0 . 2 1}$ & $\mathbf{0 . 2 2}$ & $\mathbf{0 . 2 2}$ & $\mathbf{0 . 1 5}$ & $\mathbf{0 . 2 5}$ \\
\hline
\end{tabular}

Note:

All the results are average of three trials.

Similar superscripts indicate non - significance at the corresponding critical difference

Statistical analysis was made only with the control ghee sample.

NS - non-significant

Table .3b Effect of FFA on un-organised ghee samples stored at $60^{\circ} \mathrm{C}$

\begin{tabular}{|c|c|c|c|c|c|c|}
\hline \multirow{2}{*}{ Ghee samples } & \multicolumn{7}{|c|}{ FFA \% Oleic acid } \\
\cline { 2 - 6 } & \multicolumn{7}{|c|}{ Storage time in Days } \\
\cline { 2 - 6 } & $\mathbf{0}$ & $\mathbf{5}$ & $\mathbf{1 0}$ & $\mathbf{1 5}$ & $\mathbf{2 0}$ & $\mathbf{2 5}$ \\
\hline Control & $0.60^{\mathrm{a}}$ & $0.65^{\mathrm{a}}$ & $0.68^{\mathrm{a}}$ & $0.70^{\mathrm{a}}$ & $0.74^{\mathrm{a}}$ & $0.80^{\mathrm{a}}$ \\
\hline $\mathbf{F}$ & $0.40^{\mathrm{a}}$ & $0.48^{\mathrm{a}}$ & $0.54^{\mathrm{a}}$ & $0.62^{\mathrm{a}}$ & $0.69^{\mathrm{a}}$ & $0.74^{\mathrm{a}}$ \\
\hline $\mathbf{G}$ & $0.83^{\mathrm{b}}$ & $0.87^{\mathrm{b}}$ & $0.91^{\mathrm{b}}$ & $0.94^{\mathrm{b}}$ & $0.98^{\mathrm{b}}$ & $1.20^{\mathrm{b}}$ \\
\hline $\mathbf{H}$ & $0.40^{\mathrm{a}}$ & $0.48^{\mathrm{a}}$ & $0.53^{\mathrm{a}}$ & $0.63^{\mathrm{a}}$ & $0.67^{\mathrm{a}}$ & $0.72^{\mathrm{a}}$ \\
\hline $\mathbf{I}$ & $0.92^{\mathrm{b}}$ & $0.96^{\mathrm{b}}$ & $0.99^{\mathrm{b}}$ & $1.20^{\mathrm{b}}$ & $1.24^{\mathrm{b}}$ & $1.28^{\mathrm{b}}$ \\
\hline $\mathbf{C D}(\mathbf{P}<\mathbf{0 . 0 5})$ & $\mathbf{0 . 2 1}$ & $\mathbf{0 . 1 9}$ & $\mathbf{0 . 2 2}$ & $\mathbf{0 . 2}$ & $\mathbf{0 . 2 3}$ & $\mathbf{0 . 2 5}$ \\
\hline
\end{tabular}

Note:

All the results are average of three trials.

Similar superscripts indicate non - significance at the corresponding critical difference

Statistical analysis was made only with the control ghee sample.

NS - non-significant 


\section{Storage study of market ghee samples}

\section{Peroxide value}

Peroxide value is the measure of autooxidative stability of ghee samples. Both control and market ghee samples were investigated for peroxide value during storage at $60^{\circ} \mathrm{C}$. The results obtained were presented in the table 2.

It is observed from the (Table $2 a$ and $2 b$ ) that peroxide values in all ghee increases with increase in storage period after $5^{\text {th }}$ day of storage at $60^{\circ} \mathrm{C}$. The control ghee sample developed a peroxide value of $1.4 \mathrm{mM}$ of oxygen $/ \mathrm{kg}$ of fat on $15^{\text {th }}$ day and then it rose drastically to a peroxide value of 6 on $25^{\text {th }}$ day of storage. The control, organized sector ghee samples have exhibited similar pattern of rate of peroxide development and acquiring peroxide value of 1.2 to $1.5 \mathrm{mM} . \mathrm{O}_{2} / \mathrm{Kg}$ fat on $15^{\text {th }}$ day of storage with pronounced oxidized flavour upon. Further storage the peroxide value arose shortly a value of 5.8 to 6.2 mM. $\mathrm{O}_{2} / \mathrm{Kg}$ fat on $25^{\text {th }}$ day of storage. Normally a pronounced oxidized flavour was observed on the $15^{\text {th }}$ day of storage having a peroxide value of around 1 .

Unorganized ghee samples showed wide fluctuation in rate of development of peroxides ranged from 1.42 to 1.70 $\mathrm{mM} . \mathrm{O}_{2} / \mathrm{Kg}$ fat and further storage the values rise drastically to a value ranging from 6 to $7.6 \mathrm{mM} . \mathrm{O}_{2} / \mathrm{Kg}$ fat. The samples $\mathrm{G}$ and I showed higher rate of oxidative rancidity during storage which might be due to adulteration in ghee (Ghatak and Bandyopadhyay, 1989).

\section{Free fatty acids}

The development of FFA content was evaluated for the control and different market ghee samples to study the changes with respect to hydrolytic rancidity. During storage at $60^{\circ} \mathrm{C}$ there was an increase in the value of FFA and the values are tabulated in the table (3).

The FFA content was ranged from 0.27 to $0.72 \% \mathrm{OA}$ in the market ghee samples against the value of $0.60 \%$ OA recorded for control ghee sample where as the FFA content of unorganised sector ghee samples were ranged from 0.40 to $0.93 \% \mathrm{OA}$ in the $0^{\text {th }}$ day of storage. The rate of increase in FFA was very slow and gradual, at the end of the $25^{\text {th }}$ day of storage the FFA content of control ghee was $0.80 \% \mathrm{OA}$ and the organised sector samples ranged between 0.57 to $0.96 \%$ OA for commercial ghee samples while the unorganised sector ghee samples ranged between 0.72 to $1.28 \%$ OA. There was an increase in the value of FFA was higher in unorganized sector ghee samples compared to control and market ghee samples it may be due to the uncontrolled practices followed during the preparation of unorganized sector ghee samples. The results obtained are in agreement with Chhagan (2013).

In conclusion a rapid development in the peroxide value was observed in ghee samples of un organised sector than organised sector collected from local market of Bengaluru. The study revealed that peroxide value and FFA values were higher in the unorganised sector ghee samples indicating lower storage stability compared to control and organised sector of market ghee samples at elevated storage temperature of $60^{\circ} \mathrm{C}$.

\section{References}

AOAC- Association of Official Analytical Chemists.

Chhagan S. G., 2013. A study on the physicochemical changes occurring in ghee during storage M.tech. Thesis. Submitted to National Dairy Research 
Institute (Deemed University), Karnal, India.

Cho, E, and Min, D.B.E.,2006. Mechanisms and factors for lipid oxidation, Compreh Rev Food Sci., 5:169-186.

Core Team, R (2017). R: A language and environment for statistical computing. Foundation for Statistical Computing, Vienna, Austria. URL http://www.Rproject.org/.

Gandhi K, Arora S, Pawar N, Kumar A (2013) Effect of vidarikand (extracts) on oxidative stability of ghee: a comparative study-research and reviews. J Dairy Sci Technol. 2(1):111.

Ghatak, P. K. and Bandyopadhyay, A. K., 1989. Chemical and sensory quality of ghee marketed in Calcutta and Kalyani (West Bengal) Indian Dairyman, 41:
515-518.

Jariwala, K., 2014. Analytical Techniques for the Assessment of Physico- Chemical Properties of Ghee. Forensic Science, 4(6): 216- 217.

Meghwal, K. 2011. Low cholesterol ghee: storage studies, Granulation behaviour and feeding effect on lipid profile of rats, M.tech. Thesis. Submitted to National Dairy Research Institute (Deemed University), Karnal, India.

Pawar, N, Arora, S, Bijoy, R.R and Wadhwa, B.K., 2012. The effect of Asparagus racemosus (Shatavari) extracts on oxidative stability of ghee, in relation to added natural and synthetic antioxidant. Int J Dairy Technol., 65(2): 293-299.

SP: 18 (Part XI) - 1981. ISI Handbook of food analysis part XI Dairy Products, India Standards Institution, New Delhi.

\section{How to cite this article:}

Niranjan, C. Kempanna, Akshaykumar, B.G. Shilpashree, G. Poojitha and Pralhad. 2020. Comparative Study on Keeping Quality of Market Ghee Samples. Int.J.Curr.Microbiol.App.Sci. 9(09): 2507-2512. doi: https://doi.org/10.20546/ijcmas.2020.909.313 